\title{
DO STUDENTS IN POLAND NEED FEMINISM TODAY? PRELIMINARY STUDIES
}

\author{
A. Ostaszewska \\ University of Warsaw (POLAND)
}

\begin{abstract}
The purpose of this paper is to reflect on the attitudes of students in Poland towards feminism. The recent events in Poland related to the situation of women have been the direct motive to conduct this research. During 2016 - 2018 mass women's protests (black protests) took place all over the country. Women protested against political attempts to ban abortion completely. Since then women's rights, in particular abortion rights, have become an important topic of social discussions, both online and offline.

Women's protests can be considered as the real beginning of the feminist movement in Poland. However, feminism evokes ambivalent reactions among Polish women. In my research I am interested in Polish students' attitudes towards feminism. Hence my research questions: How do masters students at the University of Warsaw perceive feminism today? Do students' views reflect the events of recent years and the current public debate in Poland? To answer these questions, I analyse students' statements on how they define feminism and whether they need it or not and why. The collected data show that students have different and ambiguous attitudes towards feminism. At the same time, their statements confirm their awareness of gender inequalities in Poland.
\end{abstract}

Keywords: Feminism, feminist, students, Poland, women's strikes, abortion.

\section{INTRODUCTION}

The situation of women in Poland has been the direct motive for undertaking this study. Over the past two years (2016-2018), citizens have taken to the streets three times as part of nationwide women's protests against political attempts to ban abortion and its penalization ([1], [2]). There were three mass protests of women in Warsaw and a number of smaller ones throughout the country and in Polish communities abroad. The protests were called "black" (as an expression of mourning). They were organized by feminist initiatives established spontaneously as a result of events in 2016 (Polish Women's Strike; Girls for Girls). On 3rd of October 2016 the first nationwide women's protest took place. About 100,000 people, women and men, participated in black protests in over 100 Polish cities and towns ([3]). Next year the international women's strike was organized on 8 March 2017. In Warsaw around 17,000 people protested (strikes were held in 80 towns and cities). Another mass protest, "Black Friday", happened on 23 March 2018. On this day 55,000 people participated in a nationwide protest that was organized in Warsaw ([4]). These protests were the first mass mobilization of women in Poland against restriction of women's right to abortion. The scale of protests shows that it was a significant success: people protested all over Poland; women and men of different age, education, socioeconomic status and views demonstrated demanding respect for women's rights ([5]). However, the question is whether this unprecedented mobilization has long-term effects? Are women's protests a real social movement representing women's interests in Poland?

The issue of abortion has been a taboo for many decades. Now it has become a topic of online and offline discussions. Black protests and women's strikes started the exchange of thoughts on reproductive rights issues, involving different voices of women. For example, a discussion about abortion coming out by a female singer, Natalia Przybysz ([6]). In an interview Przybysz confessed to abortion, saying: "Five minutes - and you have your life back. [...] I really didn't want this child" ([7]). She decided to have an abortion for social reasons: she and her husband and two children live in a small apartment where there is no room for another child. The interview comments revealed diverse views on abortion among women in Poland. They showed that women do not speak with one voice: there are women who openly demand complete liberalization of abortion law (e.g. the slogan "Abortion is OK") as well as those for whom abortion is a "necessary evil", or a "last resort" (e.g. "Let's Save Women" project). Opposition views clash in the debate on reproductive rights. This is not a question whether abortion should be legal at all, but rather whether it should be a subject to any conditions or not (abortion on request). The discussion is not only about abortion laws, but feminism and women as 
subjects with unrestricted freedom of choice. The question of abortion has become a key question whether a woman has the right to decide about herself. And that is a feminist issue.

Although feminism is not an unknown word for Polish women, a mass feminist movement in Poland never happened. The political situation in the nineteenth and twentieth century was not conducive to the development of feminism in Poland ([8]). In a situation of constant threat to the autonomy and sovereignty of the country the priority was given to the fight for independence (obtained in 1918 after 123 years of occupation) or the fight against the communist regime in the second half of the 20th century ([9], [10]).

According to feminist activist and philosopher Ewa Majewska, a real feminist movement began in Poland in 2016 and it was due to black protests. In her opinion, black protests were "not an exclusive movement of middle-class women from metropolitan elites, but nationwide mobilization" ([11]). However, this opinion seems too optimistic - there are critical voices saying that black protests have exposed the fears of modern women more than their strength. Sylwia Czubkowska claims that "Polish women strive for equality," but "not radically"; they want to be emancipated, "but not too much" etc. ([12]). Feminism evokes ambivalent reactions among Polish women and their attitude towards feminism is characterized by inconsistency ([13], [14]).

\section{METHODOLOGY}

In my research I am interested in Polish students' attitudes towards feminism. This issue seems to be particularly significant now, in the context of recent events (black protests and discussions about abortion). The main research questions are:

- How do students, observers and participants of social life, perceive feminism today? Is feminism perceived positively or negatively by students? Are they supporters or opponents of feminism and why?

- Do the events of recent years (black protests and women's strikes) and the current public debate in Poland are reflected in the opinions of these young adults?

To answer these questions, I conducted preliminary research involving one group of students - first year students of master's degree program at the Institute of Social Prevention and Resocialization at University of Warsaw. The research was voluntary - students were not obliged to participate in the study. 23 students were present on the day of research and three of them refused to complete the task. Demographic data shows that 14 students stated 1997 as their year of birth, three -1996 and two - 1995. Two participants reported their gender as male.

The research had a written form and consisted of two sentences to be completed by students: (1) "Feminism means..." and (2) "I need / I do not need feminism because...". This way of conducting the research was inspired by the campaign Who Needs Feminism? started by students of Duke University in 2012. The campaign was managed and conducted by students and its aim was to address relevance of feminism and feminist movement in today's society ([15]). It became quickly a popular social media photo campaign at Tumblr. The purpose of my study is not to educate students about feminism, nor is an online campaign targeted at young adults. It is an analysis of students' views on feminism today in Poland, in a situation where the right-wing, conservative government is seeking to ban the abortion. The role of students in this research was intended to be passive - they were only its participants.

After the students statements have been collected, I made a qualitative analysis of their content based on the methodology of grounded constructivist theory ([16]). In the analysis that follows, I highlighted several key issues that emerge during the process of coding students' statements of feminism. I consider the ways students defined what feminism means according to them. Then, I explicate two main approaches to feminism that came out of my analysis of the statements.

While quoting student statements I tried to translate their words into English literally. Students' statements have been numbered (from 1 to 19) and marked with the letter F or M depending on gender.

\section{RESULTS}

The general comment of students' statements is that they are aware of social and political situation in Poland. Although students do not refer directly to black protests (they do not mention their 
participation in the protests) they refer to the situation of women in Poland. For instant, they give examples of gender inequalities, including labour market and unequal pay for men and women. Feminism means for them:

"equality between men and women, equal access to different types of goods, equal pay for the same job" (2F).

This statement echoes the main feminist principles characteristic of the second wave of feminism (1960-1970), especially these postulated by liberal feminism: gender equality in every area of life. The key point of this perspective is that women should have the same rights as men and the same educational and work opportunities ([17], [18]).

When students were asked what feminism means, they referred to their academic knowledge and basic feminist principles. Terms such as "social movement" and "ideology" dominated in students' statements. There is also a direct reference to history of feminism (suffrage movement):

[Feminism means...] "a movement which postulates equality between women and men. One can say that feminism originates from the suffrage movement - women who fought for their right to vote. Currently, the biggest problem is gender pay gap; not promoting women for senior positions and obstructing their promotion" (9F).

Students had a chance to define feminism by themselves (in any way they wanted) but they did not involve personally or refused to tell personal stories and instead they gave a dictionary explanations. Although there is no explicit negative assessments of feminism, there are some critical views which evoke associations with a postfeminist perspective or a fourth wave feminism. Whereas second and third waves of feminism were focused on fighting for women's liberation and gender equalities on macro and micro levels ([19]), the fourth wave prioritise justice against assault and harassment, the pursuit for equal pay for equal work, and also the bodily autonomy ([20]). It has sparked a vocal "men's rights movement" as well ([21]). This statement is an example of the fourth wave perspective:

"Even today, it happens that women receive less pay for the same work as men; they are still seen as housewives and they cannot decide about their bodies" (16F).

On the other hand, postfeminism is a term used to describe a view that all or many of the goals of feminism have already been achieved ([22]). According to Susan Faludi postfeminism is a backlash against feminism ([23]). Faludi claims that American media in the 1980s used a backlash strategy to suggest that women's liberation movement of the 1970s itself was the main cause of women's problems in the next decades. Faludi claims that backlash is an historical trend which occurs when women have made substantial gains in their efforts to obtain equal rights. Popular postfeminist discourse is reflected in the following statement:

[Feminism is...] "a movement and ideology that once postulated and fought for equality between men and women. At present feminism has acquired a lot of negative connotations and I think it is more about gender war than equality. That is why I think that now the term 'feminist' is negatively marked and is perceived in this way. Despite the fact that I agree with the main idea of feminism (gender equality) I would not like to be called a feminist at the moment. I don't want to be seen as an 'undervalued woman who needs parity to break through and all she does, is cry"' (6F).

The student claims that today feminism does not meet the expectations of modern women: they do not need feminism because they do not feel worse than men. Feminism here is viewed as a movement of women who hate men and need parity to succeed. The author even distances herself from feminism. It is a result of negative perceptions of feminists: as the author states feminists are women who lead a gender war with them.

\subsection{With or without feminism}

Student statements can be divided into two main types. First type represents those students who identify themselves with feminism and support its principles openly. Second one represents postfeminist point of view - those students reject the label "feminist" but support a range of feminist principles. In these statements feminism is characterized by ambivalence: they perceive feminism as something that once was important and positive but now it "has gone too far" and affects relationships with men negatively. For example, this student claims: 
"I believe that nowadays women's rights are sufficiently guaranteed and that the feminist movement can cause conflict in society. The only exception is abortion law, which was wrongly tightened in Polish law. In this particular case, I support the feminist movement" (4F).

The author does not identify with feminism, however she recognizes the need to support feminist movement in the fight for abortion rights. This attitude is an example of what is currently happening in Poland - generally many women do not agree to tighten the abortion law. However it does not mean that these women want liberalization of abortion laws. It also does not mean that women who protest against the abortion ban, are followers of feminism or identify with it.

\subsection{Unequal pay: gender issue}

In students' opinions gender inequalities still remain in Polish society. There is a recognition of gender inequalities and a need for further social changes:

"The situation of women in Poland is getting worse every year. Women have fewer and fewer rights to decide about their health and life (e.g. the topic of abortion in Poland), they are more often humiliated and abused, and actions taken in these matters are often carried out with great reservations" (10F).

Students discuss women's current situation in terms of two main issues: abortion law and work, particularly unequal pay between men and women:

"I need feminism because the social perception of women must change. Women shouldn't be treated as people whose life goal is to raise three children and cook dinners every day. I need feminism because not every woman has to be a mother. Women should have equal opportunities to develop as men have. In terms of payment for work they should be treated in the same way as men. They should not be treated worse than men. Feminism is needed to make real changes in society: equality and equal distribution of responsibilities between men and women, the fight against stereotypes..." (9F).

The student includes gender pay gap in the larger system of gender-based social inequalities. This statement confirms the liberal feminist view that gender inequalities are ubiquitous and occur in various areas of life - from family life and household responsibilities to work, promotion and pay.

"I believe that there is a discrimination against women in workplaces - women at the same positions receive lower salaries than men. In addition, women don't get promoted at work as quick as men do. Also, I do not like the view in society that a woman should sacrifice her professional career for children" (8F).

In this statement the focus is on women's discrimination in workplace. The student comments situation of women in the labour market and assesses it as different than in the case of men. She does not agree with the statement that being a woman means being a mother first and foremost. Therefore criticism concerns traditional gender roles of women - a mother and a housewife. The author of this statement not only describes the situation of women, but also makes her personal assessment - it is evidenced by terms such as "I don't like".

From a linguistic perspective the statements about "I need / I do not need feminism..." seem quite personal. Although the students do not recall their own experiences, they express their assessments of feminism. They begin their statements with the phrases: "I think", "I believe" or "in my opinion". It is worth to notice that students rarely refer to their gender - the fact of being a woman is not synonymous with pro-feminist views. Rare were the statements in which students emphasize that they need a feminism because they are women.

\section{CONCLUSIONS}

Feminism as a concept is known to students. However they perceive feminism in an ambiguous way. It is interesting that while defining feminism, they refer to a traditional liberal feminist theory ([24]). It means they focus on equal rights and gender inequalities. The voice of liberal feminists who concerned about discrimination against women echo in students' statements. As liberal feminists, students also discuss the false belief that women by nature are less intellectually and physically capable than men ([25]). 
However, when asked whether they need feminism and why, students refer to more modern concepts, particularly postfeminism and the fourth wave of feminism. This is evidenced by statements in which students distance themselves from "old" feminism, even speaking of it as useless today. A label "feminist" is associated by them with negative stereotypical connotations. A postfeminist attitude can be found in the views of feminism becoming a negative phenomenon now ("gone too far"). On the other hand, the fourth wave of feminism is seen particularly in the statements about gender pay inequalities. Sometimes it is difficult to separate these two perspectives because they appear in one and the same statement.

As in the public debate, different opposition positions collide in the statements: feminist and postfeminist ones. The first one claims that gender equality does not exist, women are not yet equal and there is still a quest for equality. That is why feminism is needed. The second one claims that women have already gained equal rights therefore feminism is not needed. Between these opposing views there is also an indirect view in which women's problems are recognized (e.g. sexism, discrimination, tightening of abortion rights), although their authors distance themselves from feminism. Students declare that they are not feminists however they oppose gender discrimination. This means that being aware of the problems women face does not yet involve feminist views.

Evidently, there are some limitations of this study which result mainly from a small research group - it consisted of one group of first-year master students. It is a preliminary research and requires more indepth studies that would include all students of social sciences faculties at University of Warsaw. It is also recommended to include sex / gender as a main variable in the analysis.

\section{REFERENCES}

[1] E. Korolczuk, B. Kowalska, J. Ramme \& C. Snochowska-Gonzalez (ed.), Bunt kobiet. Czarne protesty i strajki kobiet. Gdańsk: Wydawnictwo ECS, 2019.

[2] A. Ostaszewska, "Black Protests - a struggle for women's subjectivity", Polish Journal of Educational Studies, vol. 71, no. 1, pp. 92-102, 2018. Retrieved from URL: https://content.sciendo.com/view/journals/poljes/71/1/article-p92.xml?lang=en

[3] "Czarny protest". Manifestacje w wielu miastach w Polsce. Ile osób wzięło udział w demonstracjach?, 2016. Retrieved from URL: http://wiadomosci.wp.pl/kat,1329,title,Czarnyprotest-Manifestacje-w-wielu-miastach-w-Polsce-lle-osob-wzielo-udzial-wdemonstracjach, wid, 18529221, wiadomosc.html

[4] Czarny Piątek dwa razy większy niż pierwszy Strajk Kobiet. "Nie będziemy kicać jak zajączki!", 2016. Retrieved from URL:

http://wiadomosci.gazeta.pl/wiadomosci/7,114883,23182956,demonstracja-dwa-razy-wieksza-nizpierwszy-strajk-kobiet.html

[5] M. Chmielewska, M. Druciarek, and I. Przybysz, Czarny protest - w stronę nowego "kompromisu aborcyjnego"?, Warszawa: Instytut Spraw Publicznych, 2017.

[6] J. Pachla, "Natalia Przybysz opowiedziała o własnej aborcji. Niestety, w sposób najgorszy z możliwych," Gazeta Wyborcza, 2016. Retrieved from URL:

https://wyborcza.pl/7,95891,20881188,natalia-przybysz-opowiedziala-o-wlasnej-aborcji-niestetyw.html

[7] P. Reiter, "Natalia Przybysz: Aborcja - mój protest song," Wysokie Obcasy, 2016. Retrieved from URL: https://www.wysokieobcasy.pl/akcje-specjalne/7,156847,20861449,natalia-przyszbyszaborcja-moj-protest-song.html

[8] A. Graff, "Gdzie jesteś, polski feminizmie? Pochwała sporu i niejasności," Krytyka Polityczna, 2014. Retrieved from URL: https://krytykapolityczna.pl/kraj/graff-gdzie-jestes-polski-feminizmiepochwala-sporu-i-niejasnosci

[9] S. Walczewska, Damy, rycerze, feministki. Kobiecy dyskurs emancypacyjny w Polsce, Kraków: "eFKa", 1999.

[10] M. Ksieniewicz, "Specyfika polskiego feminizmu," Kultura i Historia, no. 6, pp. 90-100, 2004.

[11] E. Majewska, "Słaby opór i siła bezsilnych. \#czarnyprotest kobiet w Polsce," Praktyka teoretyczna, 2016. Retrieved from URL: http://www.praktykateoretyczna.pl/ewa-majewska-slaby-opor-i-silabezsilnych-czarnyprotest-kobiet-w-polsce-2016/ 
[12] S. Czubkowska, "Feminizm jest obciachowy. I 'czarny poniedziałek' tego nie zmieni," Gazeta Prawna, 2016. Retrieved from URL: https://www.gazetaprawna.pl/artykuly/980124,feminizm-wpolsce-jest-obciachowy.html

[13] M. Frąckowiak-Sochańska, "Postawy polskich kobiet wobec feminizmu. O samo ograniczającej się świadomości feministycznej kobiet," Acta Universitatis Lodziensis. Folia Sociologica, no. 39, pp. 149-170, 2011.

[14] J. Helios, W. Jedlecka, Urzeczywistnianie idei feminizmu w ogólnoświatowym dyskursie o kobietach, Wrocław: E-Wydawnictwo. Prawnicza i Ekonomiczna Biblioteka Cyfrowa, 2018. Retrieved from URL:

http://www.bibliotekacyfrowa.pl/Content/89358/Urzeczywistnianie_idei_feminizmu.pdf

[15] R.F. Seidman, "Who Needs Feminism? Lessons from a Digital World," Feminist Studies, vol. 39, no. 2, pp. 549-562, 2013. Retrieved from journal URL: www.jstor.org/stable/23719067

[16] K. Charmaz, "Grounded Theory: Objectivist and Constructivist Methods," in Handbook of Qualitative Research (N.K. Denzin and Y.S. Lincoln eds.), 2nd ed., pp. 509-535, Thousand Oaks CA: Sage, 2000.

[17] J. Grant, Fundamental Feminism: Contesting the Core Concepts of Feminist Theory, London: Routledge, 1993.

[18] I. Whelehan, Modern Feminist Thought: From the Second Wave to 'post-feminism', Edinburgh: Edinburgh University Press, 1995.

[19] J. Lorber, Gender Inequality. Feminist Theories and Politics, New York Oxford: Oxford University Press, 2010.

[20] P. Chamberlain, The Feminist Fourth Wave, London: Springer International Publishing, 2017.

[21] J. Abrahams, "Everything you wanted to know about fourth wave feminism — but were afraid to ask," Prospect, 2017. Retrieved from URL: https://www.prospectmagazine.co.uk/magazine/everything-wanted-know-fourth-wave-feminism

[22] S. Faludi, Backlash : the undeclared war against women. London: Chatto \& Windus, 1992.

[23] E.J. Hall, M. Salupo Rodriguez, "The Myth of Postfeminism," Gender and Society, vol.17, no.6, pp. 878-902, 2003. Retrieved from URL: https://www.jstor.org/stable/3594675?seq=1\#page_scan_tab_contents

[24] S. Wendell, "A (Qualified) Defense of Liberal Feminism," Hypatia, vol. 2, no. 2, pp. 65-93, 1987. Retrieved from URL: www.jstor.org/stable/3810017

[25] R. Putnam Tong, Feminist thought: a comprehensive introduction, Boulder, Colo.: Westview Press, 4 edition, 2009. 